\title{
Screening and Identification of Upland Rice Lines Derived Recurrent Selection for Drought Tolerance
}

\author{
Reny Herawati ${ }^{\#}$, Masdar", Dwi Wahyuni Ganefianti ${ }^{\#}$, Bandi Hermawan ${ }^{\#}$, Alnopri $^{\#}$ \\ ${ }^{\#}$ Faculty of Agriculture, University of Bengkulu, Bengkulu, 38371A, Indonesia \\ E-mail: reny.herawati@unib.ac.id
}

\begin{abstract}
Variety assemblings for higher yield capacity of upland rice which tolerant to drought stress and highly adaptable to climate change has been needed to support the effort to increase both rice yield and the upland rice field extensification. This research aims to screen and identify an agronomic character of upland rice lines as the result of recurrent selection to a seedling stage on the drought stress. Materials were 180 rice lines as the result of recurrent selections from two local varieties Sriwijaya and Bugis with other two drought tolerant lines IR7858-1 and N148+. Twenty seeds each genotype were seeding in seed pods adjusted with stripe check such Situbagendit and Inpari 6 as tolerant and susceptible lines respectively. Drought stress treatment had conducted in a week, began at two weeks seedling age with a scoring value 0-9 (SES IRRI), at the same time were taken sample soil to measure the soil water content was done at a depth of $20 \mathrm{~cm}$. Then, the crops were watered again to observe the recovery capacity of the crops, with the scoring 1-9 (SES IRRI). Anatomically stomatal proximation was observed for both susceptible and tolerant rice lines. The selected lines would transplant in the field to record the yield capacity and other agronomic characters. The SES screening resulted in 53 tolerant lines, 99 moderate tolerant, and 28 susceptible to the drought stress which had the soil water content ranged from 11.9 to 12.7 percent. Anatomic stomatal observation showed that the stomatal structure and density of susceptible lines were closer and more than tolerant lines. The highest percentage of filled grains showed by the intercross line Sriwijaya/IR7858-1 about 77.4 to 85.1 percent with averagely 80.7 percent, which was a high category with the scale of 3 SES IRRI. The selected drought stress lines with better agronomic character would continuously test to know the yield capacity in the environmentally specific location.
\end{abstract}

Keywords - screening; drought tolerance; upland rice; recurrent selection

\section{INTRODUCTION}

Rice being global, especially in Asia, an important crop for most humans which have been using the grain as a staple food. The problems faced by the rice farmers today being the drought land widespread, especially in the rice belt Central Java, West Java, the northern coast of Cirebon, Indramayu, and other areas in Indonesia [1]. There extensive drought lands in Indonesia could not optimally utilize. The drought land being always without any irrigation channel. The soil water only from rainfall retained by the soil particles. Therefore the drought land generally being affected by the dry season. The drought land nature or character has been causing to limit the cultivated crops ([2], [3]).

Continuous efforts for innovative technology hopefully could overcome and reduce the climate change impact on the sustainable farming systems. The innovative technology includes drought-tolerant rice varieties. The high-yielding as well as tolerant or resistant of upland rice varieties being used for the climate change highly adaptation [4], which is highly necessary to support rice yield increase efforts as well as drought land rice extensification.
Upland rice is one of the food crops that could yield to the drought land. Upland rice development in drought land being one solution for the food security problem. The rice acreage decrease due to land use changes into not only residential but industrial plants areas, new rice fields expensiveness, and limited irrigation water, that why the upland rice actually an essential crop to cultivate [5].

Today's, the low usage of high yielding upland rice varieties due to both low available of breeder seed and low desire of seed producers to produce the superior seed. According to [6], the upland rice production constraints due to physical, biological and socio-economic reasons. The cultivation land with generally high aluminum (Al) saturated sour reaction, frequently in drought and nutrient deficiency. The desired upland rice characteristic for such a physical condition like early to moderate ripening, moderate tillering, upright stem, blast resistance, and $\mathrm{Al}$, drought, and shade tolerant. The upland rice development faces many complicated obstacles so that the high-yield varieties with biophysically multi tolerant in drought land [3]. Conventionally specific local rice breeding in drought land to improve high yield could not be done without known 
genetic constraints and the desired pattern of inheritance. Selection will provide an optimal response to the appropriate selection criteria. The most effective breeding methods to improve one or two properties that are controlled by a single gene called the backcross method. While a recurrent selection being actually to improve some characteristics controlled by many genes. Recurrent selection is a selection method and crossing selected plants from a population in a systematic way to establish a new better population ([7], [8], [9], [10]). In other words, this method is a procedure of collecting the desired characters of a combination crosses with some continuously crossing selected segregants in order to obtain better population than previous ones, due to the plants have a combination of desired characters. Reference [11] reported that recurrent selection in Wheat Bread plants could identify potential lines with high yield and drought stress tolerant for limited water resource areas. Recurrent selection techniques have also been carried out by [12] with 8 cycles to genetically estimate the progress yield of a chickpea.

Evaluation, characterization, and selection of drought stress tolerant rice crop being an essential step in plant breeding. To conduct the selection of lines especially to drought tolerance could be through morphological features of the root system of each genotype. Plant endures to drought stress by leaf area limiting, root elongation to reach wet areas, and stomatal closing to limit transpiration ([13], [14]). Stomata play an essential role in plant adaptation to drought stress. In drought conditions, the stomata would close to restrain transpiration rate. Abscisic acid (ABA) plays a role in both stomatal opening and closing. ABA plays a drought signal for the stomatal closing ([15], [16]). Crop yield as the selection criteria being efficient less for genotype tolerance assessment on drought due to complicated hard to identify the genotype high yield potential in drought stress. Screening tolerant lines in seedling phase have been made to select drought-tolerant lines ([1], [17], [18]). Reference [16] showed that successfully managed to select 78 assessed drought tolerant on the water content of $10-12 \%$ in the seedling phase with SES score 0 and 13 genotypes for the yield potential of above 1 ton/ha. Reference [19] that successfully identifying the drought stress tolerance in local upland rice with PEG. This research aimed to screen and identify agronomic characters of upland rice lines resulting recurrent selection in drought stress tolerance at seedling stage.

\section{MATERIALS AND METHODS}

\section{A. Material}

The research was conducted at the Greenhouse, and Agroecotechnology Laboratory Faculty of Agriculture, University of Bengkulu, from December 2016 to May 2017. The experiments methods accorded to the [1]. 180 lines of recurrent cross selection result derived from local rice Bengkulu crosses (Sriwijaya and Bugis) and droughttolerant lines (IR7858-1 and N148+). Plant check is Situbagendit and Inpari 6 as drought tolerant and susceptible varieties respectively.

\section{B. Rice Plantation Procedure}

Twenty seeds were sown in a plastic tub soil of $40 \times 25 \times 20$ $\mathrm{cm} .12$ line numbers arranged in each tub with the crop plant stripe check, known Situbagendit as drought tolerant and Inpari 6 as susceptible varieties.

\section{Screening Procedure}

The plant being intensively maintained, ie watering to two-week-old plants. After the phase, the plants were left without water. Drought tolerance assessed by Standard Evaluation System IRRI [20] (Table 1), at the time of susceptible plant check dies or leaves drought has dried up (score 9). At the same time, the $20 \mathrm{~cm}$ depth soil samples taken for moisture content measurement.

TABLE I

PLANT DROUGHT RESPOND CLASSIFICATION BASED ON SES IRRI (2002)

\begin{tabular}{|c|l|l|}
\hline Score & criteria & Description \\
\hline 0 & Highly tolerant & No symptoms \\
\hline 1 & Rather tolerant & Slight tip drying \\
\hline 3 & Tolerant & Tip drying extended up to $1 / 4$ \\
\hline 5 & Moderate tolerant & $\begin{array}{l}\text { One-fourth to } 1 / 2 \text { of all } \\
\text { leaves dried }\end{array}$ \\
\hline 7 & $\begin{array}{l}\text { Moderate } \\
\text { susceptible }\end{array}$ & $\begin{array}{l}\text { More than } 2 / 3 \text { of all leaves } \\
\text { fully dried }\end{array}$ \\
\hline 9 & Susceptible & $\begin{array}{l}\text { All plants apparently dead. } \\
\text { Length in most leaves fully } \\
\text { dried }\end{array}$ \\
\hline
\end{tabular}

After the whole tested lines were observed and scored based on Table 1, the plants watered and intensively cultivated again. Ten days later the plant recovery growth rate response classified with the IRRI Standard Evaluation System [20] (Table 2).

TABLE II

PLANT RECOVERY GROWTH RATE RESPONSE CLASSIFICATION AFTER DROUGHT TREATMENT BASED ON SES IRRI, 2002

\begin{tabular}{|c|l|l|}
\hline Score & \multicolumn{1}{|c|}{ criteria } & \multicolumn{1}{c|}{ Description } \\
\hline 1 & Tolerant & $90-100 \%$ plants recovered \\
\hline 3 & Rather tolerant & $70-89 \%$ plants recovered \\
\hline 5 & Moderate tolerant & $40-69 \%$ plants recovered \\
\hline 7 & Moderate susceptible & $20-39 \%$ plants recovered \\
\hline 9 & Susceptible & $0-19 \%$ plants recovered \\
\hline
\end{tabular}

\section{Stomatal Analysis}

Anatomical observation of stomatal density being also performed on susceptible lines as well as those able to adapt to drought stress with modified methods by [21]. The upper and lower surfaces of taken leaves being cleaned with tissue from dust/dirt. The cleaned leaves were fixed with $70 \%$ alcohol for 24 hours [22]. The leaves being smeared with transparent fluids, left for 24 hours, in order to get better stomatal prints. The dried smear is slowly taken with a pair of tweezers, attached to the object glasses and observed with similar 100x magnification microscope. 


\section{E. Identification of Agronomic character}

Selected lines were then planted in the experimental garden for the yield and agronomic characters. Plants planted in the land sized $2 \mathrm{~m} \mathrm{x} 3 \mathrm{~m}$. A total of 53 selected lines are used in the experiment, each line being planted in one row of 25 plants of $20 \mathrm{~cm} \mathrm{x} 20 \mathrm{~cm}$ plant spacing, which the distance between lines of $40 \mathrm{~cm}$. Fertilization dosed with $200 \mathrm{~kg}$ Urea, $100 \mathrm{~kg} \mathrm{SP} 36$ and $100 \mathrm{~kg} \mathrm{KCl}$ per hectare. The whole SP36 and $\mathrm{KCl}$ fertilizers were administered at planting time, Urea was administered three times, each onethird dose respectively at planting time, 4 weeks, and 7 weeks after planting. The whole management of pests, diseases, and weeds being done as needed. The research observations as plant height, maturity, the number of productive tillers, panicle length, the percentage of filled grains per panicle, and grain weight per hill.

\section{RESULTS AND DISCUSSION}

\section{A. Drought Tolerant Line Screening}

The screening of tolerant line at the nursery phase being carried out to select drought-tolerant lines ([1], [17], [18]). The drought-tolerant assessment was performed on both Situbagendit and Inpari 6 varieties that shown dried leaves symptoms, while soil sampling of $20 \mathrm{~cm}$ depth shown the water content between 11.9 and 12.7 percent.

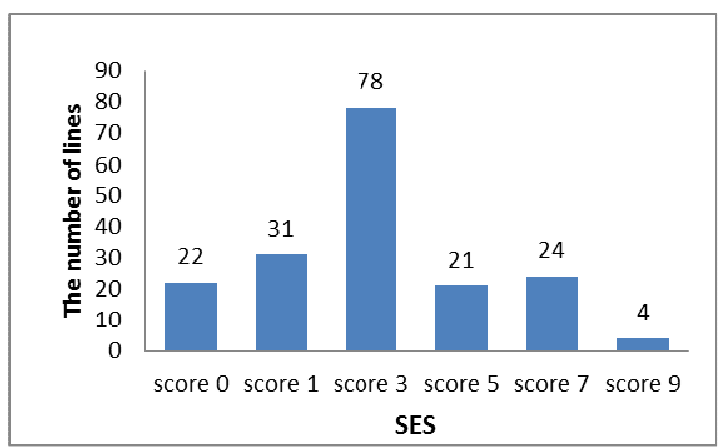

Fig. 1. Distributions of rice lines with different drought tolerance scores (in SES scale 0-9)

The assessment based on the SES (Standard Evaluation System) [20] showed 53 tolerant lines, 99 moderately tolerant lines, and other 28 susceptible lines to drought stress (Figure 1). Out of 53 drought tolerant lines at the end of the observation, only the tips of dried leaves with the score between 0 and 1, which $90-100 \%$ being able to grow back, while 99 tolerant moderate lines with the score of 3-5 which $70-90 \%$ being able to recovery grow back, and 28 susceptible lines with the score of 7-9, only 40-69\% of them being recovery grow back (score 5) (Table 3; Figure 1). Reference [17] reported in their study that during the drought stress periods, the soil water content below $30 \mathrm{~cm}$ depths ranged from 10-12\% showed 78 assessed drought tolerant in which 12 assessed with the score of $0-1,18$ assessed with the score of 1 and other 48 assessed with the score of 3 under SES IRRI. Out of these 73 accesses, the yield of 13 assessed being more than 1 ton/ha, while the yield of the tolerant line (CR 143-2-2) being 2.7 tons/ha and no yield of the control susceptible plants (IR20).
As seedling visibility shown that the plants which 7 weeks without watered, the tolerant lines kept growing well, vigorous, and the leaves remain completely open, while moderate tolerant lines showed the ends of the leaves dried up, even on vulnerable lines seen almost all the leaves rolled up, dried and wilted (Figure 2 and 3). Reference [14] reported that leaf roll being delayed on the drought-tolerant rice genotype. The rolled leaves are induced by loss of turgor and lower osmotic regulation in the rice plants, delayed leaf rolling in the tolerant genotype indicates preserved turgor and protected from dehydration. Leaf rolling mechanisms adjusted the leaf water potential to absorb soil water under drought stress [23].

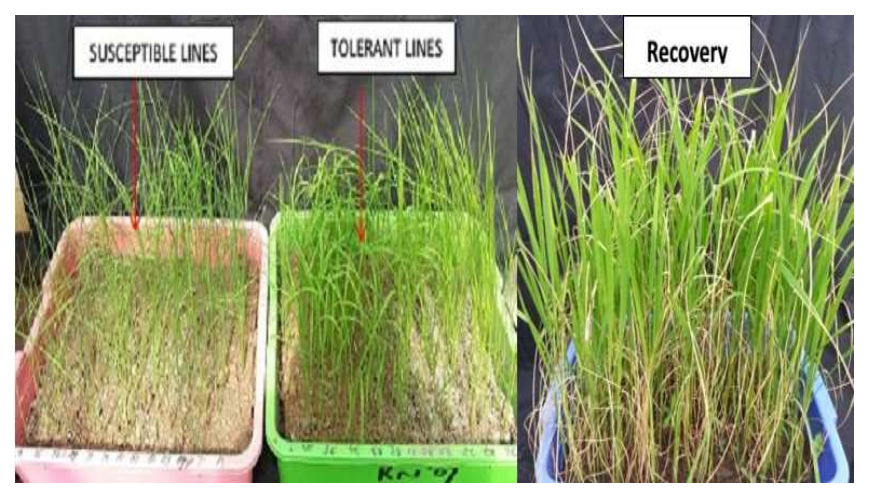

Fig. 2. The appearance of lines on the treatment of drought stress and the ability of plants to recovery grow back.

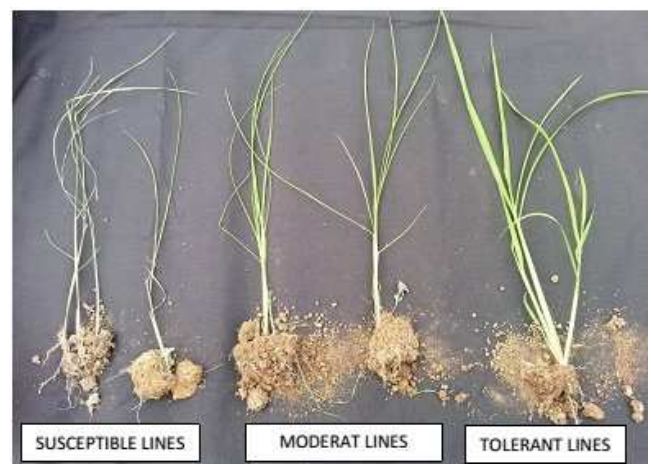

Fig. 3. Comparison of tolerant seedlings (0-1 score), moderately tolerant (score 3-5) and susceptible (score 7-9) in treating drought stress

\section{B. Stomatal Observation}

Anatomical approaches being made for stomatal observation intolerant as well as susceptible plants to drought. This approach is essential for both physiological and morphological approach in determining the susceptible and adaptable genotypes in drought stress. According to [14], drought stress affected both physiological and biochemical properties such as total chlorophyll content, photosynthesis, stomatal structure, total protein, leaf area index, relative water content, and proline content. Correlations between each character could be used as an indirect selection tool of the main characters. The indirect selection would work if the character could be measured more quickly and more accurately than the main character [24]. Stomatal density could affect two important processes, photosynthesis, and transpiration, in plants. 
TABLE III

CHOSEN LINE NUMBER WITH BOTH DROUGHT AND THE RECOVERY RESPONSE ON THE GROWTH RATE

\begin{tabular}{|c|c|c|c|c|c|c|c|c|}
\hline \multirow[b]{2}{*}{$\begin{array}{c}\text { The number } \\
\text { of Lines }\end{array}$} & \multicolumn{3}{|c|}{ Drought Response* } & \multicolumn{5}{|c|}{ Recovery* } \\
\hline & $\begin{array}{c}\text { Tolerant } \\
\text { (score } 0-1)\end{array}$ & $\begin{array}{c}\text { Moderate } \\
\text { (score 3-5) }\end{array}$ & $\begin{array}{l}\text { Susceptible } \\
\text { (Score 7-9) }\end{array}$ & 1 & 3 & 5 & 7 & 9 \\
\hline \multicolumn{9}{|l|}{53} \\
\hline \multicolumn{9}{|l|}{45} \\
\hline \multicolumn{9}{|l|}{51} \\
\hline \multicolumn{9}{|l|}{3} \\
\hline \multicolumn{9}{|l|}{4} \\
\hline \multicolumn{9}{|l|}{15} \\
\hline 9 & & & & & & & & \\
\hline \multicolumn{9}{|l|}{ stripe check } \\
\hline \multicolumn{9}{|l|}{ Situbagendit } \\
\hline Inpari 6 & & & & & & & & \\
\hline
\end{tabular}

The stomatal observation shows that the composition and density of stomata in the susceptible genotype being denser and number full than the tolerant genotype (Figure 4). The plant stomatal density being related to drought resistance [25]. Reference [13] reported that both stomatal size and the density being associated with the resistance to water stress. Plant adaptation to drought stress, could by leaf modification to reduce the leaf area. In the drought stress, stomata would close to restrain the transpiration rate. The abscisic acid (ABA) compound plays a role in both stomatal opening and closing. ABA acts as a drought stress signal to immediately closes the stomata ([15], [16]).

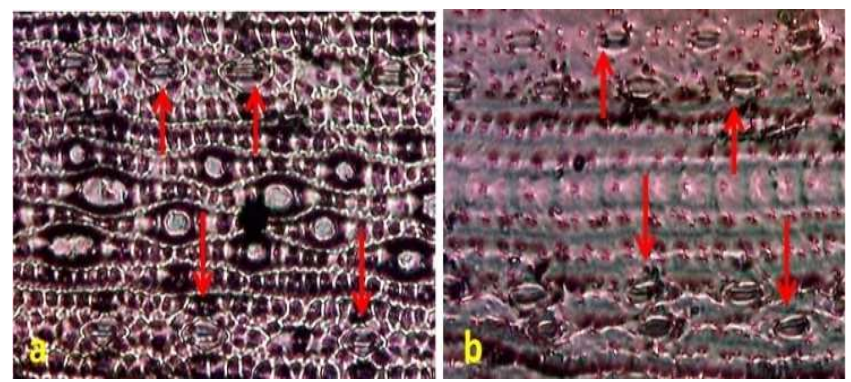

Fig. 4. Stomatal observation on the tolerant line (a) and susceptible line (b)

The selected line of drought stress being shown in Table 4. Thirteen lines from Bugis/IR7858-1 crossbreed, five lines from Bugis/N22 crossbreed, 12 line from Sriwijaya/N22 crossbreed, and 23 lines from Sriwijaya/IR7858-1 crossbreed. The lines being evaluated for both agronomic character and yield rate.

\section{Agronomic character appearance of the selected drought tolerant line}

The agronomic characteristics of selected lines being presented in Table 5. Plant height being categorized as short to high. The plant height and productive tillers being essential agronomic characters and important identity of the genotype. Reference [26] reported that plant height characters being influenced by one or two allele groups, of which one allele controlled the semi-dwarf, while the other one controlled the plant height character. The Sriwijaya/N148+ crossbreed height averagely $118.5 \mathrm{~cm}$, while the Sriwijaya/IR7858-1 crossbreed height averagely 109.7 based on the SES IRRI [19], while the ideal plant characteristics according to [27] for the plant height averagely $115-120 \mathrm{~cm}$.

TABLE IV

THE SELECTED LINE OF DROUGHT STRESS IN SEEDLING PHASE

\begin{tabular}{|l|l|c|}
\hline \multicolumn{1}{|c|}{ Crossing } & \multicolumn{1}{|c|}{ Genotype } & $\begin{array}{c}\text { The number } \\
\text { of lines }\end{array}$ \\
\hline $\begin{array}{l}\text { Bugis/ } \\
\text { IR7858-1 }\end{array}$ & $\begin{array}{l}\text { 248-1, 248-2, 248-3, 248-4, 248-5, 248- } \\
6,248-7,248-8,248-9,249-2,249-3, \\
249-4,249-5\end{array}$ & 13 \\
\hline $\begin{array}{l}\text { Bugis/ } \\
\text { N148+ }\end{array}$ & $250-11,250-12,251-1,251-2,251-3$ & 5 \\
\hline Sriwijaya/ & $\begin{array}{l}253-13,253-14,253-15,253-16,253- \\
\text { N148+ }\end{array}$ & $\begin{array}{l}17,253-18,254-1,254-2,254-3,254-4, \\
254-5,254-6\end{array}$ \\
\hline & $\begin{array}{l}256-4,256-5,256-6,256-7,256-8,256- \\
9,256-10,256-11,256-12,256-13,256-\end{array}$ & \\
Sriwijaya/ & $\begin{array}{l}14,258-3,258-4,258-5,258-6,258-7, \\
\text { IR7858-1 }\end{array}$ & 23 \\
& $\begin{array}{l}258-8,258-9,258-10,258-11,258-12, \\
258-13,258-14\end{array}$ & \\
\hline
\end{tabular}

The productive tiller number greatly varies across all crossbreeds. The Bugis/N148+ crossbreed showed the highest productive tillers range in 22 lines by SES IRRI [20]. The lines potentially produce large number panicles according to the new plant type (NPT) criteria with 330 panicles per $\mathrm{m} 2,150$ grains per panicle, $80 \%$ grain filling, $25 \mathrm{mg}$ of dry unhulled oven weight, 22 tons/ha total above ground biomass (Moisture content of $14 \%$ ), and $50 \%$ the harvest index [28]. The Bugis/IR7858-1 crossbreed showed the highest panicle length ranged from 20.7 to $26.2 \mathrm{~cm}$, averagely $22.4 \mathrm{~cm}$ (Table 5). The panicle length and the grain number per panicle correlated each other [29] when the panicle number per $\mathrm{m} 2$, the percentage of filled grains, the 
total biomass and the harvest index required for the new type of rice. Both the range and an average number of filled grain per panicle and grain weight per hill is shown in Table 5. The highest percentage of grain contents of Sriwijaya/IR7858-1 crossbreed ranged from 77.4 to 85.1 percent with an average of 80.7 percent and being categorized high on the scale of 3 SES IRRI [20]. Reference [30] suggested that low seed filling due to a low efficiency of the assimilating partition to the seed. The grain number between 180-240, with a filled grain of more than 85 percent is the ideal plant character [27]. Reference [31] reported that water stress caused significant reductions in plant height $(8$ $\mathrm{cm})$, the number of grains per panicle (18 grains), the number of tillers (2 tillers), and crop yield (12 g/plant). Averagely grain weight per hill ranged from 15.1 to 24.7 grams in almost all crossbreeds. The lines were potentially the high-yield one. The well agronomic characteristics lines of drought stress being readily tested in selected environments to determine the yield potential rate in specific environments.

TABLE V

GROUPING AND PERFORMANCE OF 53 SELECTED DROUGHT-TOLERANT LINES

\begin{tabular}{|c|c|c|c|c|c|}
\hline \multirow{2}{*}{ Crossbreeds } & \multirow{2}{*}{$\begin{array}{c}\text { The number } \\
\text { of lines }\end{array}$} & \multicolumn{2}{|c|}{ Plant height (cm) } & \multicolumn{2}{|c|}{ The number of productive tillers } \\
\hline & & Range & Average & Range & Average \\
\hline Bugis/IR7858-1 & 13 & $117-151$ & 139.5 & $2-11$ & 6.7 \\
\hline Bugis/N148+ & 5 & $125-143$ & 136.0 & $2-22$ & 5.6 \\
\hline Sriwijaya/N148+ & 12 & $112-128$ & 118.5 & $6-12$ & 8.9 \\
\hline \multirow[t]{3}{*}{ Sriwijaya/IR7858-1 } & 23 & $91-122$ & 109.7 & $3-16$ & 9.3 \\
\hline & \multirow{2}{*}{$\begin{array}{c}\text { The number } \\
\text { of lines }\end{array}$} & \multicolumn{2}{|c|}{ Maturity } & \multicolumn{2}{|c|}{ Panicle length $(\mathrm{cm})$} \\
\hline & & Range & Average & Range & Average \\
\hline Bugis/IR7858-1 & 13 & $114-125$ & 121.5 & $20.7-26.2$ & 22.4 \\
\hline Bugis/N148+ & 5 & $110-116$ & 113.6 & $20.5-22.1$ & 21.3 \\
\hline Sriwijaya/N148+ & 12 & $114-120$ & 118.5 & 20.4-22.5 & 21.7 \\
\hline \multirow[t]{3}{*}{ Sriwijaya/IR7858-1 } & 23 & $115-123$ & 119.2 & $20.5-23.0$ & 21.9 \\
\hline & \multirow{2}{*}{$\begin{array}{c}\text { The number } \\
\text { of lines }\end{array}$} & \multicolumn{2}{|c|}{$\begin{array}{l}\text { Percentage fill } \\
\text { grain/panicle }\end{array}$} & \multicolumn{2}{|c|}{ Grain weight/hill (g) } \\
\hline & & Range & Average & Range & Average \\
\hline Bugis/IR7858-1 & 13 & $71.1-77.2$ & 74.2 & $15.3-24.7$ & 21.1 \\
\hline Bugis/N148+ & 5 & $72.7-81.3$ & 77.1 & $15.1-23.1$ & 18.8 \\
\hline Sriwijaya/N148+ & 12 & $72.6-84.6$ & 81.6 & $15.5-22.2$ & 19.7 \\
\hline Sriwijaya/IR7858-1 & 23 & $77.4-85.1$ & 80.7 & $15.3-22.5$ & 18.9 \\
\hline
\end{tabular}

\section{CONCLUSIONS}

The screening based on SES results in 53 tolerant lines, 99 moderate tolerant lines, and 28 susceptible lines to drought. Anatomical observation to stomata shows that stomatal composition and density of susceptible genotype being more denser and number full compared to the tolerant genotype. The highest percentage of fill up grain at Sriwijaya/IR7858-1 crossbreed ranged from 77.4 to 85.1 percent, averagely 80.7 percent and being categorized as high based on the 3rd SES IRRI scale. Selected lines with good agronomic characteristics in drought being recommended for further testing to determine the potential yield rate in the specific environments.

\section{ACKNOWLEDGMENT}

We would like to thank Sahri Yono (undergraduate student at Agroecotechnology Study Program, University of Bengkulu), and Dadi (farmer) for their assistance in the field works. This funding research has been proposed to National
Strategic Research of Ministry of Research, Technology and High Education, Indonesia.

\section{REFERENCES}

[1] E. Lubis, R. Hermanasari, Sunaryo, A. Santika, and E. Suparman Toleransi galur padi gogo terhadap cekaman abiotik. Apresiasi Hasil Penelitian Tanaman Padi, Litbang Pertanian. hlm 725-739. 2007.

[2] R.H. Wening and U. Susanto. "skrining plasma nutfah padi terhadap cekaman kekeringan. Widyariset, 17(2):193-204. 2014.

[3] E. Lubis, Z. Harahap, M. Suwarno, Diredja, H., and Siregar. "Perbaikan varietas padi gogo untuk wilayah perhutanan beriklim kering”. Risalah Hasil Penelitian Balittan, Bogor. 1993.

[4] N.N. Thuy and H.H. Anh."Vulnerability of Rice Production in Mekong River Delta under Impacts from Floods, Salinity and Climate Change". IJASEIT 5(4):272-279. 2015.

[5] A. Rachman, I. Purwani, T.C. Wahono, Mardawilis, Emilya, Firman, Khadir, Sinaga, P.H. and Rivana, C. "Pengkajian Sistem Usaha Pertanian (SUP) Berbasis Padi Gogo". 2003. http:// www.pustaka.bogor.net/patek /apt1250.htm.5 October 2006.

[6] A. Kaher A. "Perbaikan varietas padi gogo pada lahan kering marginal". In: Syam, M., Hermanto, Musaddad A, Sunihardi, editor. Kinerja Penelitian Tanaman Pangan. Pusat Penelitian dan Pengembangan Tanaman Pangan, Badan Litbang Pertanian. pp 448-459. 1993. 
[7] B. Abdullah. "Progress of rice improvement through recurrent selection". J. Agron. Indonesia 37(3): 188 - 193 . 2009.

[8] A.P.C.G. Berilli, M.G. Pereira, R.D.S. Trindade, F.R.D. Costa, and K.S.D. Cunha. "Response to the selection in the 11th cycle of reciprocal recurrent selection among full-sib families of maize". Acta Scientiarum, Agron 35: 435-441. 2013.

[9] O.P.Morais Júnior., P.G.S. Melo, O.P. Morais, O.P. Castro, F. Breseghello, M.M. Utumi, J.A. Pereira, F.J. Wruck, and J.M.C. Filho. "Genetic progress after cycles of upland rice recurrent selection". Sci. Agric. 72(4):297-305.2015.

[10] R. Herawati, E. Inoriah, Rustikawati, Mukhtasar. "Genetics Diversity and Characters Agronomic of F3 Lines Selected by Recurrent Selection for Drought Tolerance and Blast Resistance of Bengkulu Local Rice Varieties". IJASEIT 7(3):922-927. 2017.

[11] P. Ramya, G.P. Singh, N. Jain, P.M. Singh, M.K Pandey, K. Sharma, A. Kumar, Harikrishna, and K.V. Prabhu. "Effect of recurrent selection on drought tolerance and related morpho-physiological traits in bread wheat". PlosOne (DOI:10.1371/journal.pone.0156869) 11(6):1-17. 2016.

[12] G.S. Silva, M.A.P. Ramalho, Â.F.B. Abreu, and J.A.R. Nunes. "Estimation of genetic progress after eight cycles of recurrent selection for common bean grain yield". Crop Breed. Appl. Biotechnol. 10(4):351-356. 2010.

[13] Z. Xu and G. Zhou. "Responses of leaf stomatal density to water status and its relationship with photosynthesis in a grass". J. of Exp. Botany, 59(12): 3317-3325. 2008

[14] S. Kumar, S. K. Dwivedi, S. S. Singh, S. K. Jha, Lekshmy S , R. Elanchezhian, O. N. Singh, and B. P. Bhatt. "Identification of drought tolerant rice genotypes by analysing drought tolerance indices and morpho-physiological traits". SABRAO J. of Breed and Gen 46(2):217-230. 2014.

[15] A.D. Golec and I. Szarejko. "Open or close the gate - stomata action under the control of phytohormones in drought stress conditions". Plant Sci 4(138)1-16.2013.

[16] J. Li, Y. Li, Z. Yin, J. Jiang, M. Zhang, X. Guo, Z. Ye, Y. Zhao, H. Xiong, Z. Zhang, Y. Shao, C. Jiang, H. Zhang, G. An, N. C. Paek, J. Ali, and Z. Li. "OsASR5enhances drought tolerance through a stomatal closure pathway associated with $\mathrm{ABA}$ and $\mathrm{H} 2 \mathrm{O} 2$ signalling in rice". Plant Biotech J 15(183-196). 2017.

[17] P. Swain, M. Anumalla,, S. Prusty, B. C. Marndi, and G.J. N. Rao. "Characterization of some Indian native land race rice accessions for drought tolerance at seedling stage". Australian J Crop Sci 8(3):32433. 2014.
[18] S. Kumar, S.K. Dwivedi, A.A Haris, V.Prakash, S. Mondal, and S.K Singh. "Screening and identification of rice genotypes for drought tolerance at reproductive stage under rainfed lowland condition". $J$. of Agri Search 2(2): 105-111. 2015.

[19] R.D. Wijoyo, A. Ete, and Adrianton. "Identifikasi toleransi kekeringan padi gogo lokal Tanangge pada berbagai larutan PEG". e-J. Agrotekbis 2(2):114-120. 2014.

[20] IRRI. "Standard Evaluation System for Rice". International Rice Testing Program. The International Rice Testing Program (IRTP) IRRI Los Banos, Philippines. 2002.

[21] S. Haryanti. "Jumlah dan Distribusi Stomata pada Daun Beberapa Spesies Tanaman Dikotil dan Monokotil". J. Bul. Anat. dan Fisiol, 18(2). 2010

[22] T. Radoukova. "Anatomical mutability of the leaf epidermis in two species of Fraxinus L. In a region with autot ransport pollution". $J$. Biotech. \& Biotechnol 23: 405-409. 2009.

[23] S. Bunnag and P. Pongthai. "Selection of Rice (Oryza sativaL.) Cultivars Tolerant to Drought Stress at the Vegetative Stage under Field Conditions". American J. of Plant Sci. , 4:1701-1708. 2013.

[24] G. Wricke and W.F. Weber. "Quantitative Genetic and Selection in Plant Breeding”. New York: Walter de Gruyter. 1986.

[25] K.J. Mc Cree and S.D. Davis. "Effect of water stress and temperature on leaf and on size and number of epidermal cells in grain sorghum". Crop Science14: 751-705. 1994.

[26] B. Warman, I. Suliansyah, E. Swasti, A. Syarif, and H. Alfi "Selection and Semi-Dwarf Allele Mutants Segregation Pattern as the Result of Gamma Ray Irradiation of West Sumatera Black Rice". IJASEIT 5(5):362-365. 2015.

[27] J. Ma, W.B.Ma, D.F. Ming, S.M. Yang, Q.S. Zhu. "Characteristics of rice plant with heavy panicle". Agric. Sci. in China 5(12): 911918. 2006.

[28] S. Peng and G.S. Khush."Four decades of breeding for varietal improvement of irrigated lowland rice in the International Rice Research Institute". Plant Prod. Sci. 6:157-164.2003.

[29] S. Peng, G.S. Khush, P. Virk, Q. Tang, Y. Zou. "Progress in ideotype breeding to increase rice yield potential". Review. Field Crops Research. 108:32-38. 2008.

[30] T. Kobata and K. Iida. "Low grain ripening in the new plant type rice due to shortage of assimilate supply". New directions for a diverse planet: Proceedings of the $4^{\text {th }}$ International Crop Science Congress Brisbane, Australia, 26 Sep - 1 Oct 2004. 2004.

[31] A.Ahmadikhah, and A. Marufinia. "Effect of reduced plant height on drought tolerance in rice". Biotech 6(221):1-9 (open access at Springerlink.com). 2016. 